\title{
Hypothesis: Erythema nodosum leprosum is precipitated by an imbalance of $T$ lymphocytes
}

\author{
R N MSHANA \\ Armauer Hansen Research Institute, PO Box 1005, Addis Ababa, \\ Ethiopia
}

Received for publication 23 April 1981

\begin{abstract}
Summary Erythema nodosum leprosum (ENL) has so far been taken as an immune complex mediated disease. Failure to demonstrate these complexes in or around blood vessels showing perivasculitis in a substantial number of patients with ENL has never been clearly explained. It is proposed that initiation of ENL is mediated by an imbalance of T lymphocytes, especially suppressor $\mathrm{T}$ cells, leading to modulation of polymorphonuclear leukocyte function.
\end{abstract}

Erythema nodosum leprosum (ENL) occurs as a complication mainly in patients with lepromatous leprosy and few with borderline lepromatous leprosy. Clinically it is characterized by crops of tender erythematous skin nodules most commonly on the face, forearms and thighs lasting only a few days. Sometimes it can also affect nerve trunks causing them to be swollen, tender and painful. Nerve abscesses have been reported to occur during ENL attacks. Other manifestations include uveitis, orchitis, lymphadenitis, arthritis and glomerulonephritis. Histologically, the hallmark of the lesions is perivasculitis, initially the infiltrating cells are polymorphonuclear leukocytes $(\mathrm{PMN})$ replaced later by mononuclear cells. ${ }^{1-3}$ This clinico-pathological picture is usually seen when most of the bacilli in the tissues are granulated or fragmented and presumably non-viable. These histological findings in conjunction with the demonstration of immunoglobulin, complement and mycobacterial antigen deposits around blood vessels in some ENL lesions, as well as circulating immune complexes (ICs) in lepromatous leprosy, have been the basis of the concept that ENL is an immune complex mediated disease, akin to a type III Arthus reaction. ${ }^{4-6}$ Demonstration of ICs in or around blood vessels is not universally found in ENL lesions, ${ }^{4,5,7}$ various figures being reported. Although these discrepancies might depend on the 
timing of the biopsy relative to the onset of the ENL, ${ }^{8,9}$ the numbers of ENL lesions without demonstrable ICs around blood vessels might indicate another pathogenic mechanism. Lucio phenomenon is thought to have pathogenetic mechanism similar to ENL, and thus occurs in the lepromatous end of the spectrum. ${ }^{10}$ It has, however, been reported recently that 3 patients with tuberculoid leprosy had developed Lucio phenomenon. ${ }^{11}$ This would argue strongly against a primary role for the immune complexes theory. Antibodies to Mycobacterium leprae have been found in the aqueous humour of leprosy patients and the evidence suggests that they are locally produced. The high level of these antibodies does not seem to be related to the classification of the patient, but rather to the presence of enlarged corneal nerves. ${ }^{12}$ Uveitis as a complication of leprosy, however, occurs only during ENL. Similarly, in vitro experiments with skin tissues from leprosy patients show that antibodies reacting with $M$. leprae, together with complement components, can be synthesized locally in these patients. ${ }^{13,14}$ Intradermal injection of $M$. leprae into lepromatous patients does not, however, elicit a classical Arthus type of reaction. ${ }^{15}$ Lepromatous leprosy has some immunological features similar to diffuse cutaneous leishmaniasis, amongst which is specific anergy to the causative agent in the presence of circulating antibodies to their respective antigens. However, ENL-like lesions do not develop in leishmaniasis.

Arthus reaction is defined as a localized acute necrotizing vasculitis. PMN and complement components have been shown to be essential for its pathogenesis. In experimental animals an Arthus reaction develops when IgG antibody and antigen combine at a vessel wall after either is initially presented at an extravascular site. Neutrophils are thought to be recruited by the action of $\mathrm{IgG}$ alone or by leuko-attractants released after it has reacted with complement components. Neutrophil attraction and vasculitis is, however, not an exclusive property of Arthus reaction as it has been shown to occur in experimental allergic encephalomyelitis (EAE) produced in rhesus monkeys ${ }^{16}$ and other animals. ${ }^{17}$ EAE is induced in animals by injection of a low molecular weight myelin basic protein (MBP) from the central nervous system. On histological examination of the brain, typical delayed type hypersensitivity reaction is found and this disease can be transferred by living, washed lymphocytes but not with serum. MBP can, however, induce EAE lesions accompanied by intense PMN infiltration and fibrinous exudates even though anti-MBP antibody neither causes in vivo PNS or in vitro CNS demyelination. ${ }^{18,19}$ Further, PPD, which classically induces delayed-type hypersensitivity, can elicit an early and predominantly PMN leukocyte infiltration in some individuals. The recruitment of PMN in acute vasculitis, therefore, need not be exclusively due to antibody-mediated reactions, but may on certain occasions be due to delayed-type-hypersensitivity reactions. Recently, it has been shown that cyclophosphamide given in small doses can enhance Arthus reaction in guinea-pigs. ${ }^{20}$ Since the action of cyclophosphamide in enhancing DNCB 
sensitization, ${ }^{21}$ Jones-Mote reaction and tuberculin response is thought to be on rapidly dividing suppressor T cells,${ }^{20}$ it may be implied that Arthus reaction is also under the influence of $\mathrm{T}$ suppressor cells, whereby a decrease in the suppressor cells enhances Arthus reaction.

Human lymphocytes are a heterogenous population of cells, broadly subdivided into $\mathrm{T}$ lymphocytes ( $\mathrm{T}$ cells) and B lymphocytes (B cells). Within each group there are further sub-classes reflecting different physiological functions. Suppressor $\mathrm{T}$ cells (Ts) are a distinct population whose role in pathogenesis of human diseases is just beginning to come to light. ${ }^{22-26} \mathrm{~A}$ decrease in the $T$ cells function leads to a concomitant increase of helper or effector functions which might be deleterious to the patient. ${ }^{22,24,26-31}$ $\mathrm{T}$ cells mediating cell-mediated immunity produce a number of soluble products termed lymphokines. These lymphokines have a variety of biological functions, including increased vascular permeability to circulating proteins and polymorphonuclear and mononuclear cell accumulation. They have also been implicated in pathogenesis of tissue injury, for example by promotion of platelet aggregation and production of thrombin-like materials which lead to vascular occlusion secondary to thrombosis. Human PMN leukocytes, on the other hand, have a high content of neutral proteases within their granules which are released upon phagocytosis. These enzymes can cause tissue damage and stimulate lymphocyte proliferation as well as producing inflammatory response histologically indistinguishabie from delayed hypersensitivity, in the absence of added antigen. ${ }^{32}$ These substances, therefore, apart from causing local tissue damage, may act on resident mononuclear cells causing further release of lymphokines which in turn increase lysosomal enzyme and protease secretions by resident cells thus aggravating injury to blood vessels.

The cause of anergy in lepromatous leprosy is poorly understood, but recently the suggestion that suppressor cells are actively involved has been put forward. A decrease of this function during the disease process is expected to disturb this delicate balance and might be reflected in certain functional tests. It has recently been shown that whereas contact sensitivity to dinitrochlorobenzene (DNCB) is depressed in lepromatous leprosy, it is on the other hand not impaired or greatly attenuated during ENL, ${ }^{33}$ indicating a depression of suppression. In addition, using monoclonal antibodies to different subsets of $\mathrm{T}$ cells, it has been shown that there is a depression of suppressor cells during ENL with a concomitant increase in vitro phytohaemagglutinin (PHA) response, although in vivo responses to $M$. leprae were not affected. ${ }^{34}$ Factors known to precipitate ENL are many and varied. They seem to share very little in common in terms of immune complexes. Further, despite circulating anti-M. leprae antibodies, not all LL patients develop ENL as a complication. Most of the factors associated with the precipitation of ENL can, however, be taken as causing a disturbance in the T-cell balance, favouring a drop of the suppressor cells. Thus, a strongly positive Mantoux test which can precipitate 
ENL can be thought of as a decrease of suppression. In some LL patients ENL occurred within $48 \mathrm{~h}$ of smallpox vaccination and increased in intensity up to $8-10$ days. ${ }^{35}$ This can also be explained by a disturbance of the $\mathrm{T}$ cell subpopulations starting with an increase in suppressor cells, as is common with viral infections, and then followed by a decrease of this population which results in ENL precipitation. Since it is live viruses which have been implicated in the induction of suppressor cells, it is important to note that intradermal inoculation with heat-inactivated virus did not precipitate or exacerbate ENL. ${ }^{35}$ Furthermore, it has been reported that in children with erythema nodosum, together with pulmonary tuberculosis, conversion to Mantoux positivity occurred at the time of appearance of the erythema nodosum. This can now be thought of as loss of cell-mediated suppression. Based on these observations, therefore, it is proposed that ENL is initiated by a decrease, absolute or relative, of suppressor $\mathrm{T}$ cells. This hypothesis can explain clinical observations that are difficult to explain using the immune complex theory. ${ }^{4,5}$ For example, large amounts of bacillary antigen and anti- $M$. leprae antibodies are always present in LL patients but not all LL patients develop ENL. Further, diverse factors known to precipitate ENL can be brought together by this hypothesis. It has been known for a long time that although ENL can occur in untreated patients, it is more frequent in patients receiving effective anti-leprosy chemotherapy. This has been thought to be due to rapid killing of $M$. leprae with release of antigens. Mice infected with large doses of BCG, develop a systemic disease with appearance of anergy to P.P.D. This anergy is thought to be mediated by suppressor $T$ cells. Recently, it has been shown that early specific chemotherapy in these animals leads to a dramatic decrease of these suppressor cells, probably by reducing the numbers of viable organisms. By delaying chemotherapy, the established suppressor $\mathrm{T}$ cells were still able to suppress P.P.D. responses in vitro even when the numbers of viable bacilli had been tremendously reduced. ${ }^{36}$ In all these animals, intradermal responses to P.P.D. were persistently negative. This would be an interesting model to study ENL in the sense that chemotherapy, although unable to completely abolish the suppression, can induce an imbalance between the helper and suppressor functions, and this may be enough to initiate ENL. It is therefore felt that the increased incidence of ENL in treated patients is not only due to antigenic release but rather due to the disturbance in T-lymphocyte subpopulations and the capacity of the individual patient to manifest such change. This can explain why some patients, despite effective chemotherapy never develop ENL. The clinical picture that can vary from acute to chronic ENL can also be taken as a function of the time-interval between these T-cell imbalances. Patients in whom decreases in suppression occur frequently and at short time-intervals will be expected to develop chronic ENL. The perpetuation phase of ENL will depend on many factors amongst which are the local presence of $M$. leprae or its antigens in tissues and antibodies towards these antigens. 
The distinction of the 2 phases of ENL, namely the initiation and perpetuation phases, may be of relevance in the design and trial of drugs. Drugs that are able to prevent the depression of suppressor cells will be expected to prevent ENL attacks from occurring. Cyclosporin-A, a non-toxic immunosuppressant, ${ }^{37-39}$ has been shown to increase the proportion of suppressor $\mathrm{T}$ lymphocytes with a concomitant clinical improvement in patients with primary biliary cirrhosis. ${ }^{26}$ Due to nephrotoxicity, however, long-term use could not be assessed. A drug with similar effects, but non-toxic, would then be ideal for a clinical trial in diseases thought to have T-cell imbalance, like multiple sclerosis, ${ }^{22,23}$ primary biliary cirrhosis ${ }^{26,30,31}$ and now ENL. Thalidomide, a very effective agent in ENL, has not been reported to be able to prevent ENL from occurring, lending further support to the 2 phases of ENL Syndrome. Thalidomide has also been reported to have beneficial effects in other diseases, most of them having very little in common as far as immune complexes are concerned. This drug also has no blanket effect on all immune complex mediated diseases. That it is effective within 24 hours of administration, indicates that its effect is not due to the solubilization or immobilization of immune complexes. It may, on the other hand, be acting on activated $\mathrm{T}$ cells reducing their actions and thus its beneficial effect in ENL. It would therefore be interesting to study the effect of this drug in multiple sclerosis, primary biliary cirrhosis and acute graft versus host $(\mathrm{GVH})$ reaction.

In summary, it is proposed that there are 2 phases on ENL, the initiation and perpetuation phases. The initiation phase is proposed to be due to an imbalance of T-cell subsets with a decrease of suppressor T cells. Experiments designed to test this hypothesis by following T-cell imbalances in lepromatous leprosy patients are underway.

\section{Acknowledgement}

The Armauer Hansen Research Institute is supported by the Norwegian and Swedish Save the Children Organizations. My thanks to W O Muluwork Tesfay, who typed the manuscript.

\section{References}

1 Job CK, Gude S, Macaden VP. Erythema nodosum leprosum. A clinicopathologic study. Int $J$ Lepr, 1964; 32: 177-84.

2 Mabalay MC, Helwig EB, Tolentino JG, Bonford CH. Histopathology and histochemistry of erythema nodosum leprosum. Int J Lepr, 1965; 33: 28-49.

3 Ridley DS. Skin biopsy in leprosy. Published by Ciba-Geigy Ltd., Basel, 1977.

4 Waters MFR, Turk JL, Wemambu SNC. Mechanisms of reactions in leprosy. Int J Lepr, 1971; 39: 417-28. 
5 Wemambu SNC, Turk JL, Waters MFR, Rees RJW. Erythema nodosum leprosum: a clinical manifestation of the Arthus phenomenon. Lancet, 1969;2: 933-5.

6 Gelber RH, Epstein V, Fasal P, Drutz DJ. Erythema nodosum leprosurn: an immune complex disease. Int J Lepr, 1973;41: 553-4.

${ }^{7}$ Faber WR, Leiker DL, Cormane RH. Immunofluorescence studies in reactional leprosy with relevance to treatment. Arch Dermatol Res, 1978; 261:323-30.

8 Braveman IM, Yen A. Demonstration of immune complexes in spontaneous and histamine-induced lesions and in normal skin of patients with leukocytoclastic angitis. $J$ Invest Dermatol, 1975; 64: 105-12.

9 Cream JJ, Bryceson ADM, Ryder G. Disappearance of immunglobulin and complement from the arthus reaction and its relevance to studies of vasculitis in man. $\mathrm{Br} J$ Dermatol, 1971; 84: 106-9.

10 Rea TH, Ridley DS. Lucio's Phenomenon: A comparative histological study. Int J Lepr, $1979 ; 47: 161-6$.

11 Miranda RN. Lucio Phenomenon in Tuberculoid Leprosy. In: Latapi F, Sail A, Rodriguez D, Malacara M, Browne SG. eds. Leprosy: Proceedings of the XI Int. Lepr. Congress, Mexico City, 13-18 November, 1978. Excerpta Medica, Amsterdam, Oxford Frinceton, i 980: pp. 265.

12 Campinchi R, Cottenot E, Dufier JL, Bloch-Michel E, Dorey C, Guyer JL. Intraocular production of leprous antibodies. In: Immunology and immunopathology of the eye. New York: Masson Publishing, U.S.A., 1979; 90-2.

13 Lai A Fat RFM, Chan Pin Jin J, Dulk DM, van Furth R. In vitro synthesis of humoral factors (Immunoglobulins and Complement) in lesional skin of leprosy patients. Infect Immun, 1979; 25: 891-5.

14 Lai A Fat, Chan Pin Jin J, van Furth R, Harboe M. In vitro synthesis of anti-mycobacterial antibodies in biopsies from skin lesions of leprosy patients. Infect Immunol, 1980; $27: 297-301$.

15 Skinsnes GK. Lepromin and the Arthus reaction. Int J Lepr, 1977; 45 : 373-7.

16 Field EJ, Raine CS. Experimental allergic encephalomyelitis in the rhesus monkey: an electron microscopic study. J Neurol Sci, 1969; 8: 839-41.

17 Lampert P. Electron microscopic studies on ordinary and hyperacute experimental allergic encephalmyelitis. Acta Neuropath, 1967; 9: 99-126.

18 Saida T, Saida K, Silberberg DH, Brown MJ, Lisak RP, Asbury AK, Manning MC. In vivo demyelination induced by serum from animals with experimental allergic encephalomyelitis (EAE). Neurology, 1978; 28: 393-4.

19 Seil FJ, Falk GA, Kies MW, Alvord EC Jr. The in vitro demyelinating activity of sera from guinea-pigs sensitized with whole CNS and with purified encephalitogen. Exp Neurol, 1968; 22: 545-55.

20 Dwyer JM, Parker D, Turk JL. Suppression of delayed type hypersensitivity to tuberculin by antigenic competition. A positive immunoregulatory mechanism sensitive to cyclophosphamide. Imminol, 1981;42: 549-59.

21 Maguire HC, Ettore VL. Enhancement of Dimitrochlorobenzene (DNCB) contact sensitization by cyclophosphamide in guinea-pigs. J Invest Dermatol, 1969; 48: 39.

22 Bach MA, Phan Dinh Tuy F, Tournier-Lassere E, et al. Deficit of Suppressor T cell in active multiple sclerosis. Lancet, 1980; 2: 1221-3.

23 Kung PC, Goldstein G, Reinherg EL, Schlossman SF. Monoc!onal antibodies defining distinctive human T-cell surface antigens. Science, 1979; 206: 347-9.

24 Reinherz EL, Weiner HL, Hauser SL, Cohen JA, Dijtaso JA, Schlossman SF. Loss of suppressor $\mathrm{T}$ cells in active multiple sclerosis. Analysis with monoclonal antibodies. $N$ Engl J Med, 1980; 303: 125-9.

25 Reinherz EL, Schlossman SF. The differentiation and function of human lymphocytes. Cell, 1980; 19: 821-7. 
${ }^{26}$ Routhier G, Epstein O, Janassy G, Thomas HC, Sherlock S, Kung PC, Goldstein G. Effects of Cyclosporin-A on suppressor and inducer T lymphocytes in primary biliary cirrhosis. Lancet, 1980; 2: 1223-6.

27 Reinherz EL, Schlossman SF. Regulation of immune response - induced and suppressor T lymphocyte subsets in human beings. $N$ Engl J Med, 1980; 303: 370-3.

${ }^{28}$ Reinherz EL, Rubinstein A, Seha RS, Strelkankas AJ, Rosen FS, Schlossman SF. Abnormalities of immunoregulatory $\mathrm{T}$ cells in disorders of immune function. $N \mathrm{Engl}$ J Med, 1979; 301: 1018-22.

29 Reinherz EL, Parkman R, Rapperport J, Rosen RS, Schlossman SF. Aberrations of Suppressor $\mathrm{T}$ cells in human graft-versus-host disease. $N$ Engl $\mathrm{J}$ Med, 1979; 300: $1061-8$.

30 Dienstag JL, Weaue JR, Wands JR. Abnormalities of lymphocyte regulation in primary biliary cirrhosis. Gastroenterology, 1978; 75: 960.

31 Zefferman RK, Wolfjen. Suppressor Cell activity in primary biliary cirrhosis. Dig Dis Sci, 1980; 25: 104-7.

32 Gottlieb AA, Maziarz GA, Tamaki N, Sutcliffe SB. The effects of dialyzable products from human leukocyte extracts on cutaneous delayed-hypersensitivity response. J Immunol, 1980; 124: 885-92.

33 Rea TH, Levan NE. Variations in Dinitrochlorobenzine responsivity in untreated leprosy: evidence of a beneficial role for anergy. Int J Lepr, 1980;48: 120-5.

${ }^{34}$ Bach MA, Wallach D, Chatenoud L, Cottenst F. T-cell subsets analysed by monoclonal antibodies in leprosy patients. International Conference on Immunological aspects of Leprosy, Tuberculosis and Leishmaniasis, Addis Ababa, 27-30 October, 1980.

35 Shah K, Mittal MM, Ray SN. Consequences of Small Pox vaccination in leprosy patients. Infect Immunol, 1973; 8: 301-8.

36 Collins FM, Watson SR. Effect of chemotherapy on suppressor T cells in BCG infected mice. Immunol, 1980; 40: 529-37.

${ }^{37}$ Borel JF, Feurer C, Gubler HJU, Stahelin H. Biological effects of Cyclosporin-A: a new anti-lymphocy tic agent. Ag Act, 1976; 6: 468-75.

38 Powels RL, Clink HM, Spence D, Morgenstern G, Watson JG, Selby PJ, Woods M, Barret A, Jameson B, Sloane J, Lawler SD, Kay HEM, Lawson D, McElwain TJ, Alexander P. Cyclosporin-A to prevent $\mathrm{CVH}$ disease in man after allogeneic bone marrow transplantation. Lancet, 1980; i: 327-9.

39 Markinck JR, Chamlegs JD, Hobbs JR, Pegrum GD. Timing of Cyclosporin-A therapy for abrogation of HVG and GVH responses in rats. Lancet, 1979; ii: 1037-9. 